\title{
Struktur Komunitas dan Kelimpahan Fitoplankton dan Zooplankton pada Musim Penghujan di Zona Intertidal Pantai Selatan Yogyakarta
}

\author{
Ratih Ida Adharini* dan Namastra Probosunu \\ Departemen Perikanan Fakultas Pertanian, Universitas Gadjah Mada \\ Jl. Flora 1A Gedung A4 Bulaksumur, Sleman, Yogyakarta, 55281 \\ Email: ratih.adharini@ugm.ac.id
}

\begin{abstract}
Community Structure and Abundance of Phytoplankton and Zooplankton on Wet Season in Intertidal Zone of South Coast of Yogyakarta
\end{abstract}

\begin{abstract}
Plankton is an organism that plays an important role as a water food reserve, which is influenced by environmental conditions. This study aims to determine the community structure, abundance and biodiversity of phytoplankton and zooplankton in the intertidal zone of south coast of Yogyakarta during the rainy season. The research was conducted at Pantai Drini, Kukup, and Sundak of Gunungkidul District during December 2016 - February 2017. Sampling was conducted on three observation stations in the intertidal zone of Drini Beach, Kukup, and Sundak twice a month. The water samples were taken with plankton nets number 25, then were fluidized in $4 \%$ formalin and stored at low temperatures. The results showed diversity index of plankton in Kukup Beach in January at 1.86 while the lowest value in February at Sundak Beach was 0.87 . The highest plankton abundance in January at Sundak Beach was 900 individu $L^{-1}$ while the lowest value in December at Kukup Beach was 217.8 individu $L^{-1}$. Based on the diversity index of Shannon-Wiener, intertidal coast waters of Yogyakarta in wet season is categorized as moderate, and dominance index is categorized as low.
\end{abstract}

Keywords: intertidal zone, community structure, abundance, plankton

\begin{abstract}
Abstrak
Plankton merupakan organisme yang berperan penting sebagai cadangan makanan perairan dan dipengaruhi oleh kondisi lingkungan. Penelitian ini bertujuan untuk mengetahui struktur komunitas, kelimpahan dan keanekaragaman plankton pada zona inertidal pantai selatan Yogyakarta selama musim penghujan. Penelitian dilakukan di Pantai Drini, Kukup, dan Sundak Kabupaten Gunungkidul selama bulan Desember 2016 - Februari 2017. Pengambilan sampel dilakukan pada tiga stasium pengamatan di zona intertidal Pantai Drini, Kukup, dan Sundak setiap dua minggu. Sampel air diambil dengan jaring plankton nomor 25, kemudian sampel plankton difiksasi dalam formalin $4 \%$ dan disimpan pada suhu rendah. Hasil penelitian menunjukan indeks keanekaragaman jenis plankton tetinggi di Pantai Kukup pada bulan Januari sebesar 1,86 sedangkan nilai terendah pada bulan Februari di Pantai Sundak sebesar 0,87. Kelimpahan plankton tertinggi pada bulan Januari pada Pantai Sundak sebesar 900 individu $\mathrm{L}^{-1}$ sedangkan nilai terendah pada bulan Desember di Pantai Kukup yaitu 217,8 individu L-1. Berdasarkan indeks keanekaragaman Shannon-Wienner maka indeks keanekaragaman di pantai selatan Yogyakarta tergolong rendah-sedang dengan indeks dominansi tergolong rendah.
\end{abstract}

Kata kunci: zona intertidal, struktur komunitas, kelimpahan, plankton 


\section{PENDAHULUAN}

Zona intertidal sebagai wilayah peralihan sehingga hanya organisme tertentu yang mampu beradaptasi terhadap perubahan fisik dan kimia akibat adanya pasang surut. Plankton merupakan organisme mikroskopis yang berhabitat di perairan tawar, laut dan samudera (McManus \& Woodson 2012). Plankton merupakan salah satu komponen mayor dari struktur trofik pembentuk jaring-jaring makanan yang berperan penting dalam keseimbangan ekosistem perairan (Acevedo-Trejos et al., 2015). Plankton dari jenis fitoplankton merupakan sumber produksi organik yang berperan sebagai dasar dari rantai makanan dan penentu kesehatan ekosistem perairan (Paerl et al., 2003; Nursuhayati et al., 2013). Fitoplankton mampu merefleksikan kualitas perairan yang ditunjukkan dengan adanya perubahan struktur komunitas, pola distribusi dan proporsi dari spesies-spesies yang sensitif terhadap perubahan lingkungan (Gharib et al., 2011). Bahkan beberapa spesies fitoplankton dapat digunakan sebagai bioindikator terjadinya kondisi eutrofikasi suatu perairan (Nawrocka \& Kobos 2011). Sedangkan zooplankton berperan penting secara biologis dalam siklus karbon dan elemen penting lainnya di perairan laut dan samudera (El-Sherbiny et al., 2011).

Kemelimpahan, distribusi, dan struktur komunitas plankton pada ekosistem laut dipengaruhi oleh suhu, kecerahan, salinitas, angin (Chai et al., 2016; Cheriton et al., 2007), serta pengaruh nutrisi dan eutrofication baik secara naturogenik maupun antropogenik (Bužančić et al., 2016). Stratifikasi menyebabkan perbedaan cahaya dan nutrient sehingga mempengaruhi struktur komunitas fitoplankton (Mena et al 2019). Tekanan alam akibat perubahan iklim dan eutrofikasi mampu mempengaruhi komposisi dan distribusi fitoplankton (Fehling et al., 2012), sedangkan global warming berdampak pada perubahan struktur jaringjaring makanan dan dinamika kesuburan plankton (Almen \& Tamelander, 2020). Zooplankton di perairan pantai yang mempunyai kemampuan untuk melakukan migrasi vertikal dan lateral juga mempengaruhi distribusi dan kelimpahan plankton (Naylor, 2006). Lapisan permukaan dari perairan biasanya didominasi oleh plankton yang mempunyai kemampuan berenang kuat (Cheriton et al., 2009). Kehadiran musuh alami plankton yaitu grazers dan parasit turut mempengaruhi kelimbahan dan struktur komunitas plankton (Alves-de-Souza et al., 2015).

Pantai Sundak, Drini, dan Kukup Kabupaten Gunungkidul Yogyakarta yang dibuka sebagai tempat pariwisata tentu saja mempengaruhi kondisi ekologi di perairan tersebut, termasuk mempengaruhi kelimpahan dan struktur komunitas plankton yang berperan sebagai penyeimbang ekosistem. Masukan dari faktor antropogenik di daerah pantai mempengaruhi distribusi dan kelimpahan plankton (Gharib et al., 2011). Selain itu, perubahan parameter fisika dan kimia perairan yang diakibatkan oleh perubahan musim juga turut memengaruhi distribusi dan komposisi biota perairan (Sharma et al., 2015). Sehingga penelitian ini bertujuan untuk mengetahui pada kelimpahan (N), dan struktur komunitas plankton vang meliputi keanekaragaman $\left(H^{\prime}\right)$, dan dominansi (D) plankton yang terdapat di Pantai Sundak, Drini, dan Kukup pada musim penghujan. Hasil yang diperoleh dari penelitian ini diharapkan dapat memberikan informasi terkait kesuburan dan kondisi perairan di ketiga pantai tersebut saat musim penghujan dalam upaya menjaga kestabilan ekosistem pantai.

\section{MATERI DAN METODE}

Penelitian ini dilaksanakan pada bulan Desember 2016 - Februari 2017 pada tiga stasiun pengamatan di masing-masing zona intertidal Pantai Sundak, Drini, dan Kukup. Stasiun pengamatan berada pada jarak 5 meter ke arah laut dan masing-masing stasiun berjarak $10 \mathrm{~m}$. Pengambilan sampel dilakukan dengan interval 2 minggu sekali. Pengambilan sampel plankton mengacu pada Standard Method (APHA, 1981) sampel plankton diambil menggunakan plankton net bernomor 25 dengan ukuran mata jaring 64 $\mu \mathrm{m}$. Pengambilan sampel plankton dilakukan dengan cara mengambil air Pantai Sundak, Drini, dan Kukup sebanyak 20 L menggunakan wadah bejana plastik 
kemudian disaring menggunakan plankton net lalu dihasilkan sampel air sebanyak $50 \mathrm{ml}$ pada botol flakon dari plankton net. Sampel air hasil penyaringan tersebut lalu dimasukan dalam botol film kemudian diberikan formalin dengan konsentrasi $4 \%$. Sampel air disimpan dalam lemari pendingin untuk mencegah kerusakan saat tidak diamati.

Pengamatan sampel dilakukan di Laboratorium Ekologi Perairan Departeman Perikanan Fakultas Pertanian Universitas Gadjah Mada. Pengamatan sampel dilakukan menggunakan mikroskop merek Olympus $\AA$ menggunakan perbesaran 100x. Sampel air tersebut kemudian dimasukan ke dalam SR (Sedgwick Rafter) sebanyak lebih kurang $1 \mathrm{~mL}$ kemudian diamati di bawah mikroskop. Pengamatan dilakukan dengan menghitung jumlah plankton dan mengidentifikasikan jenis plankton yang teramati pada SR di semua bidang pandang. Plankton yang teramati kemudian diidentifikasikan menggunakan buku "The Plankton of South Vietnam (Shirota, 1996).

Plankton yang teridentifikasi kemudian dihitung nilai indeks keanekaragaman, kerapatan, dan dominansinya. Keanekaragaman plankton dihitung dengan menggunakan rumus Indeks Keanekaragaman Shannon-Winner (Odum, 2005). Untuk mengetahui kepadatan plankton digunakan rumus persamaan modifikasi lackey drop (APHA 2005). Analisis dominansi digunakan untuk mengetahui apakah terdapat plankton jenis tertentu yang mendominasi di sebuah perairan. Perhitungan indeks dominansi Simpson's (Odum, 2005).

Pengukuran kualitas air merupakan data pendukung dalam penelitian ini. Uji kualitas air yang dilakukan meliputi parameter fisik dan kimia. Parameter yang diuji meliputi pengukuran suhu air dan udara, $\mathrm{pH}$, saliitas, curah hujan, pasang surut, serta substrat dasar perairan.

\section{HASIL DAN PEMBAHASAN}

Plankton yang ditemukan di zona intertidal Pantai Sundak terdiri dari 36 genera dan 46 spesies. Pada zona intertidal Pantai Drini ditemukan plankton terdiri dari 37 genera dan 54 spesies (Gambar 2). Pantai Kukup terdiri dari 89 genera dan 173 spesies (Gambar 1). Persentase jenis plankton di Pantai Sundak, jenis plankton yang paling banyak ditemukan Synedra tabulata sebanyak $31,3 \%$. Persentase jenis plankton di Pantai Drini terlihat bahwa jenis plankton yang paling banyak ditemukan Tintinopala sp. sebanyak 10,8\%. Persentase jenis plankton di Pantai Kukup maka jenis plankton yang paling banyak ditemukan Skeletonema costatum dan Tintinnopsis butschlii sebanyak $7,57 \%$ (Gambar 3). Secara keseluruhan fitoplankton kelas Bacillariophyceae dan zooplankton kelas Oligotrichea mendominasi di ketiga pantai. Kehadiran Leptocylindrus spp. menjadi petunjuk bahwa di ketiga pantai telah mengalami eutrofikasi lokal. Menurut (Rath et al., 2018). Leptocylindrus spp. Merupakan salah satu spesies indikator terjadinya eutrofikasi akibat masukan nutrient berlebih.

Nilai kelimpahan plankton pada zona intertidal Pantai Sundak berkisar antara 478,8900 individu $L^{-1}$, pada Pantai Drini berkisar antara 217,8-509,4 individu $\mathrm{L}^{-1}$, dan pada Pantai Kukup sebesar 217,8-309,6 individu $L^{-1}$. Kelimpahan tertinggi sebesar 900 individu $\mathrm{L}^{-1}$ terdapat pada pantai Sundak, sedangkan terendah sebesar 217,8 pada Pantai Drini dan Kukup. Kelimpahan plankton tertinggi yang berada di Pantai Sundak diduga karena topografi pantai yang menghadap langsung ke laut tanpa ada penghalang dan relative dangkal sehingga relatif mempunyai gelombang cukup tinggi. Hal ini berdampak pada penambahan nutrient yang berasal dari dasar laut hingga menuju pantai. Namun, kelimpahan tertinggi di Pantai Sudak hanya didominasi oleh fitoplankton dan zooplankton jenis tertentu yang tahan terhadap perubahan kondisi perairan dan tingginya gelombang. Sedangkan Pantai Kukup yang mempunyai kelimpahan paling rendah diduga karena topografi Pantai Kukup yang lebih tertutup, dangkal, dan dengan gelombang cukup tenang sehingga mempengaruhi masukan nutrient dan intensitas matahari hingga ke dasar. McManus \& Woodson (2012) menyatakan bahwa pertukaran air, tingginya nutrien, dan tingginya tingkat pencahayaan mempengaruhi peningkatan pertumbuhan 
fitoplankton yang diikuti pula dengan meningkatnya zooplankton (McManus \& Woodson 2012).

Kemelimpahan plankton juga dipengaruhi oleh musim terkait dengan suhu dan pencahayaan, sehingga kelimpahan plankton di ketiga pantai selama musim tersebut tergolong rendah karena pada musim penghujam pencahayaan menurun. Hal ini diperkuat oleh pernyataan El Sherbiny et al. (2011) dimana kelimpahan plankton terjadi mulai pada musim semi dan mencapai puncaknya pada musim panas ketika pencahayaan melimpah. Kelimpahan plankton pada bulan Desember pada ketiga pantai tergolong rendah dibandingkan dengan bulan-bulan lainnya karena pada bulan Desember mempunyai curah hujan paling tinggi $(600 \mathrm{~mm})$ sehingga memicu turbiditas perairan. Turbiditas yang tinggi akan mengurangi penetrasi cahaya yang masuk ke perairan sehingga berakibat pada penurunan kelimpahan fitoplankton akibat terganggunya proses fotosintesis. Hal ini juga diperkuat oleh Sharma et al. (2015), dimana ketika terjadi peningkatan sedimentasi maka pertumbuhan fitoplankton di Sungai Garhwal Himalaya menjadi menurun. Intensitas hujan yang tinggi pada bulan Desember membantu membawanya nutrient dari daratan sehingga pada bulan Januari dan Februari (setelah puncak musim hujan) kesuburan perairan cenderung meningkat sehingga meningkatkan pula kelimpahan plankton pada musim-musim tersebut. Fluktuasi curah hujan mempengaruhi masukan nutrient dalam perairan sehingga berdampak pada komunitas fitoplankton dan blooming alga (Qiu et al., 2016). Masukan nutrient ke perairan mempengaruhi distribusi dan kelimpahan plankton dalam perairan (Bužančić et al., 2016).

Indeks keanekaragaman pada zona intertidal Pantai Sundak berkisar antara 0,871,25. Nilai tersebut menunjukan tingkat keragaman dan kestabilan komunitas plankton pada tingkat rendah hingga sedang. Indeks keanekaragaman pada zona intertidal Pantai Drini berkisar antara 1,09-1,26 yang menunjukkan bahwa tingkat keanekaragaman dan kestabilan komunitas plankton tergolong sedang. Indeks keanekaragaman pada Pantai Kukup berkisar antara 1,46-1,86 yang menunjukkan bahwa tingkat keanekaragaman dan kestabilan komunitas plankton tergolong sedang. Secara umum, indeks keanekaragaman plankton tertinggi terdapat di Pantai Kukup yang mengindikasikan bahwa perairan tersebut masih tergolong baik. Keanekaragaman yang tinggi merupakan indikator adanya keseimbangan ekosistem dalam perairan tersebut (Bužančić et al., 2016). Keanekaragaman yang plankton yang tinggi di Pantai Kukup terjadi karena topografinya yang relative tertutup dan kondisi pantai yang cenderung dangkal daripada Pantai Drini dan Sundak sehingga penetrasi cahaya matahari cenderung tinggi sehingga memicu kesuburan dan keanekaragaman plankton di perairan tersebut.

Nilai indeks dominasi pada zona intertidal pada Pantai Sundak berkisar antara 0,08-0,19; pada Pantai Drini berkisar antara 0,07-0,11; dan pada Pantai Kukup 0,01-0,05. Dominansi paling tinggi pada pengambilan sampel di Pantai Sundak pada bulan Februari sebesar 0,19 sedangkan dominansi paling rendah pada pengambilan sampel di bulan Januari sebesar 0,01 pada Pantai Kukup. Dominansi terendah terjadi di Pantai Kukup karena pantai tersebut mempunyai keanekaragaman plankton yang lebih tinggi dibandingkan dengan Pantai Sundak dan Drini. Sedangkan dominansi tertinggi terjadi pada Pantai Sundak yang mempunyai keanekaragaman relative rendah dibandingkan dengan pantai yang lain. Dominansi membuat ketidaksinambungan ekosistem yang dapat disebabkan oleh adanya tekanan atau gangguan dari lingkungan, sehingga beberapa jenis tertentu saja yang dapat bertahan hidup. Dominansi yang tinggi disebabkan oleh adanya suatu jenis spesies oportunistik tertentu yang tahan terhadap lingkungan perairan tersebut dan mempunyai kemampuan untuk melakukan reproduksi secara cepat sehingga mendominasi niche tersebut yang menyebabkan penurunan keanekaragaman komunitas plankton (Bužančić et al., 2016). Jenis plankton yang paling banyak ditemukan di zona intertidal Pantai Sundak yaitu Syenedra tabulate. Pada zona intertidal Pantai Drini spesies yang paling banyak 


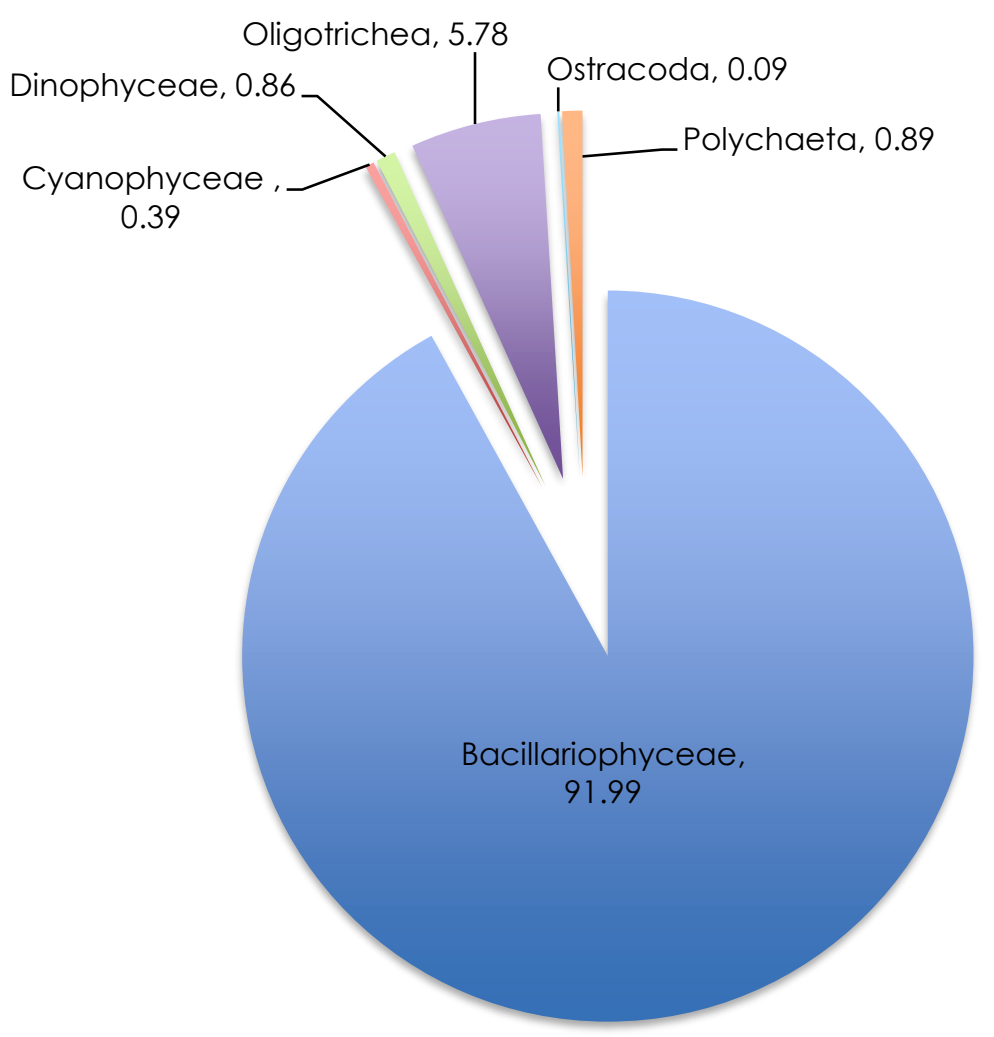

Gambar 1. Keanekaragaman dan komposisi jenis plankton di Pantai Sundak

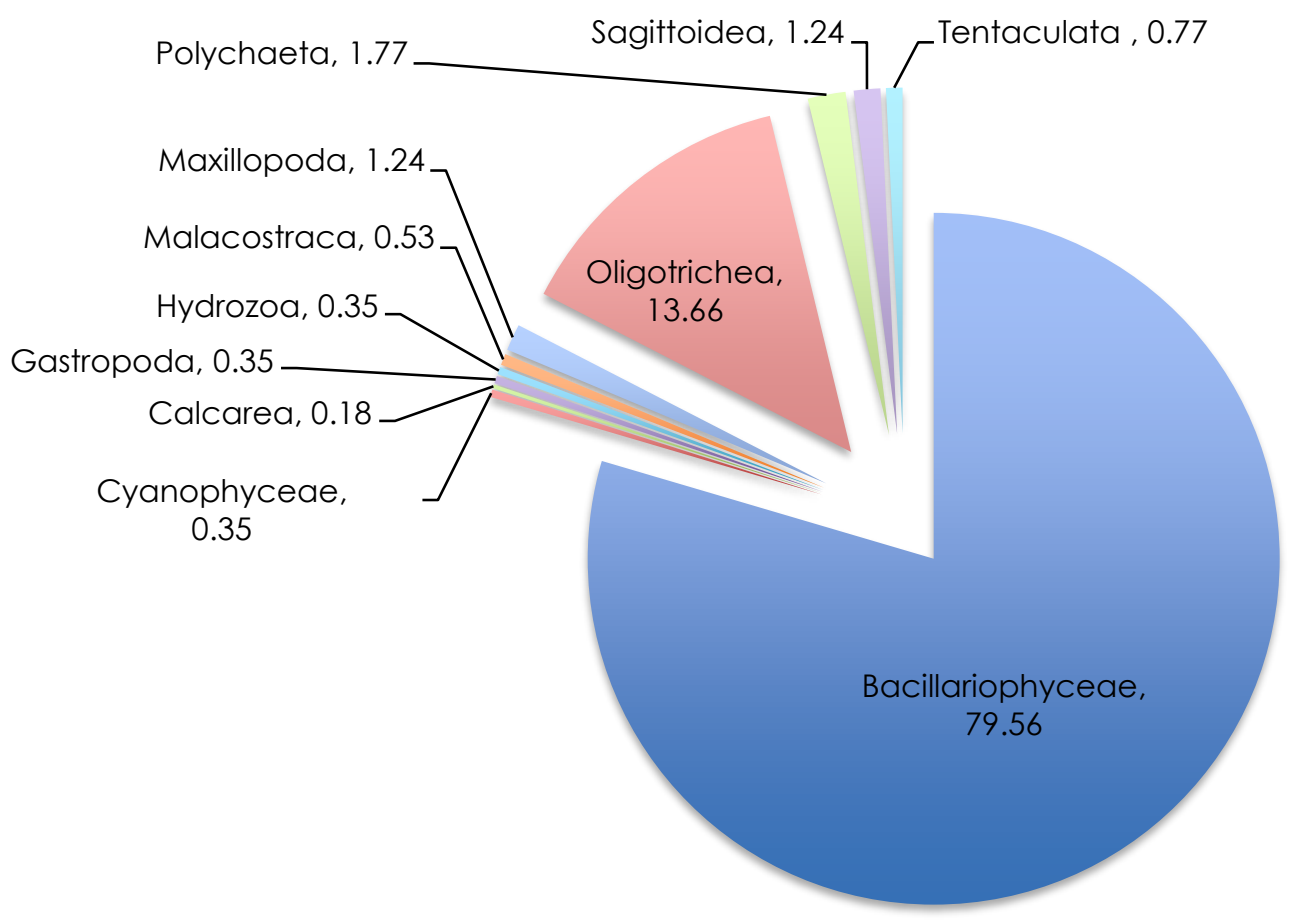

Gambar 2. Keanekaragaman dan komposisi jenis plankton di Pantai Drini 


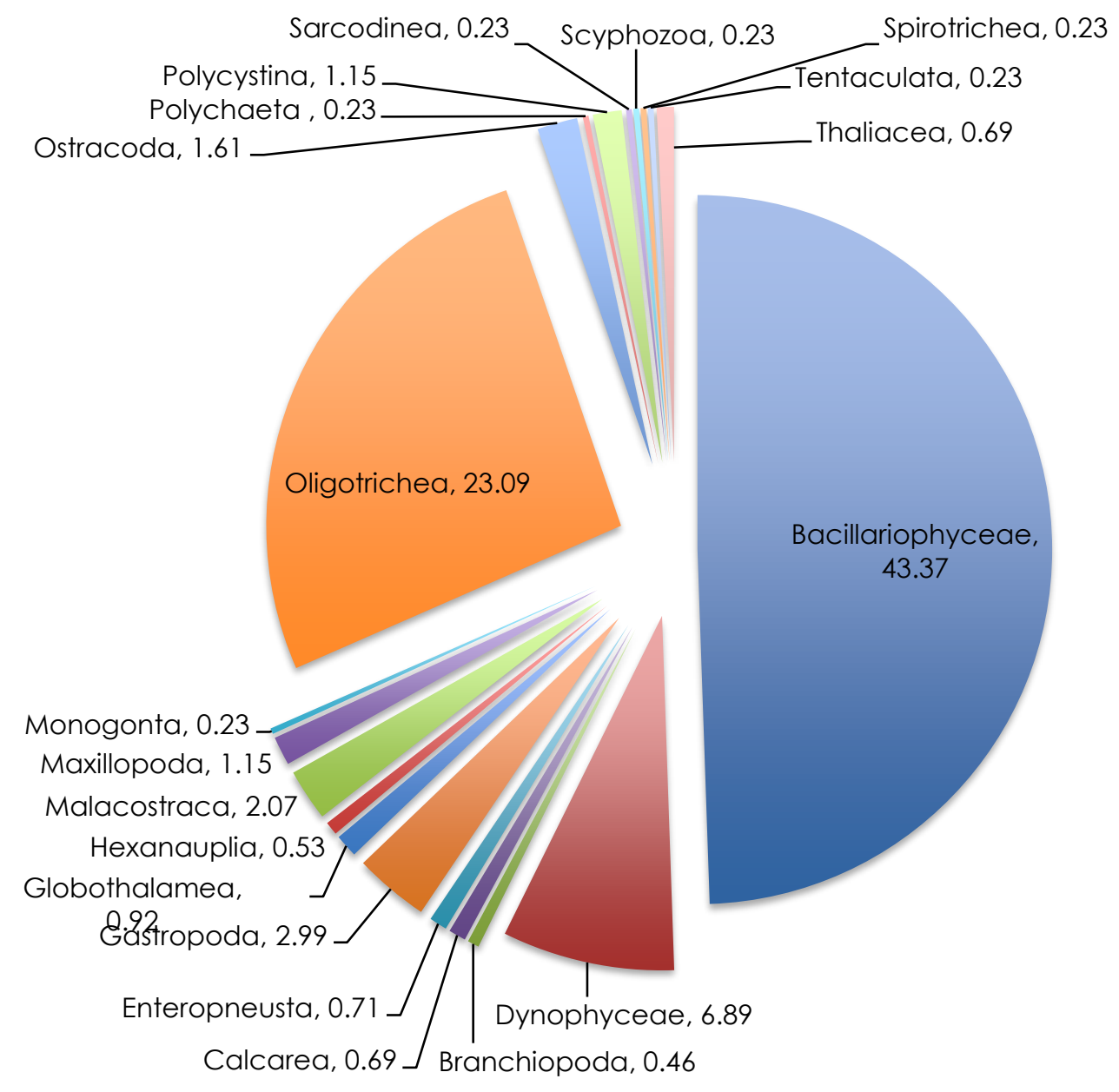

Gambar 3. Keanekaragaman dan komposisi jenis plankton di Pantai Kukup

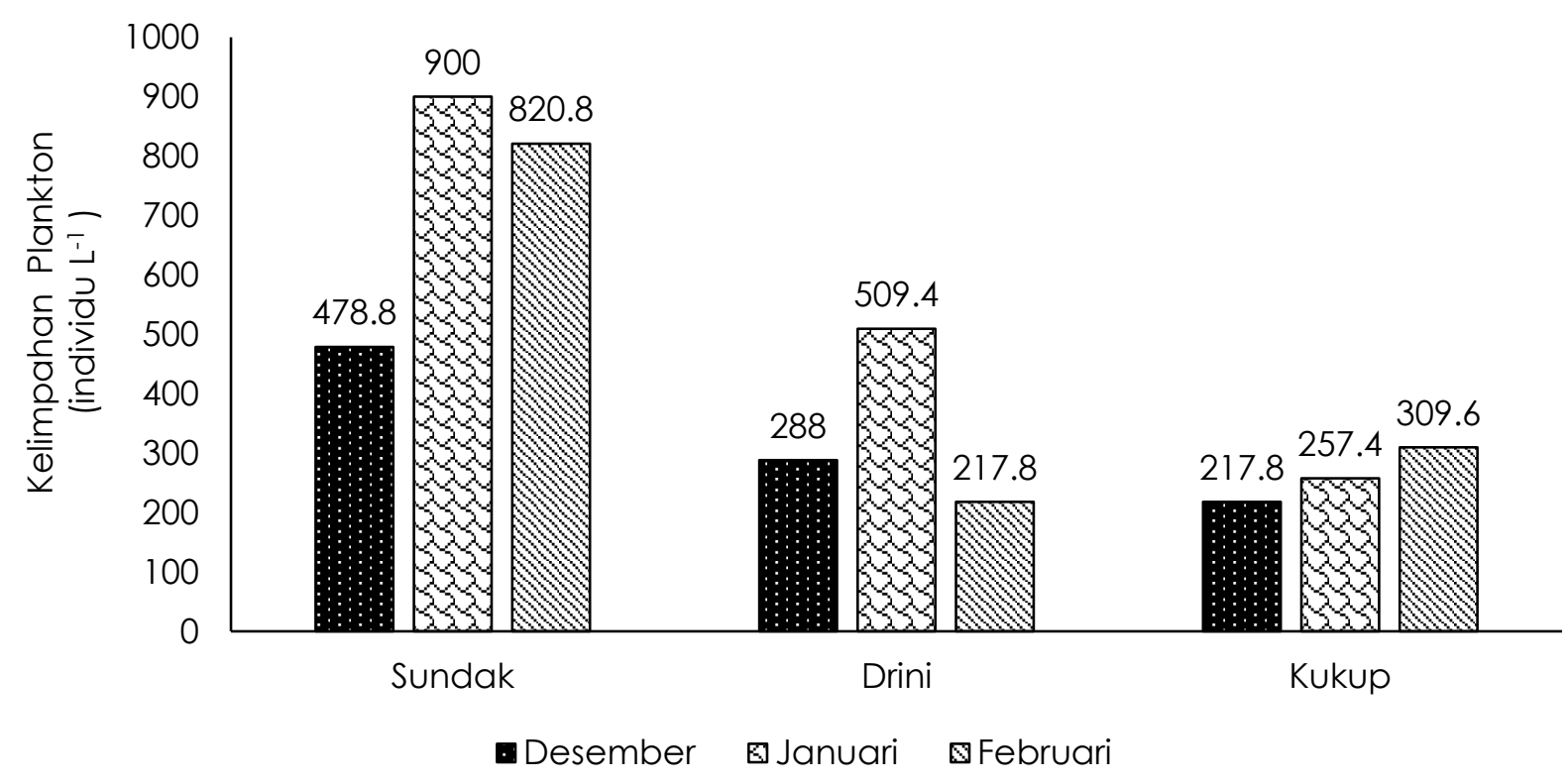

Gambar 4. Kelimpahan plankton antar pantai 


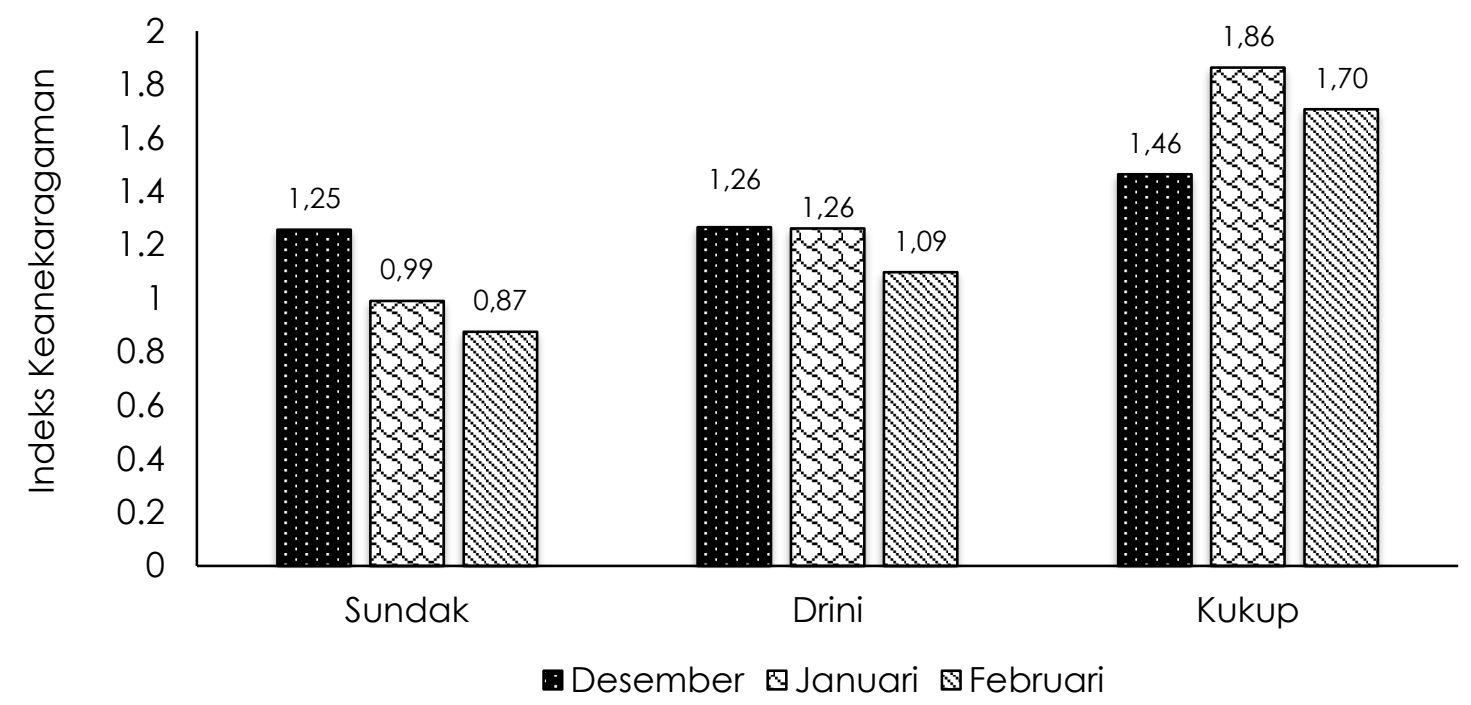

Gambar 5. Indeks keanekaragaman plankton antar pantai

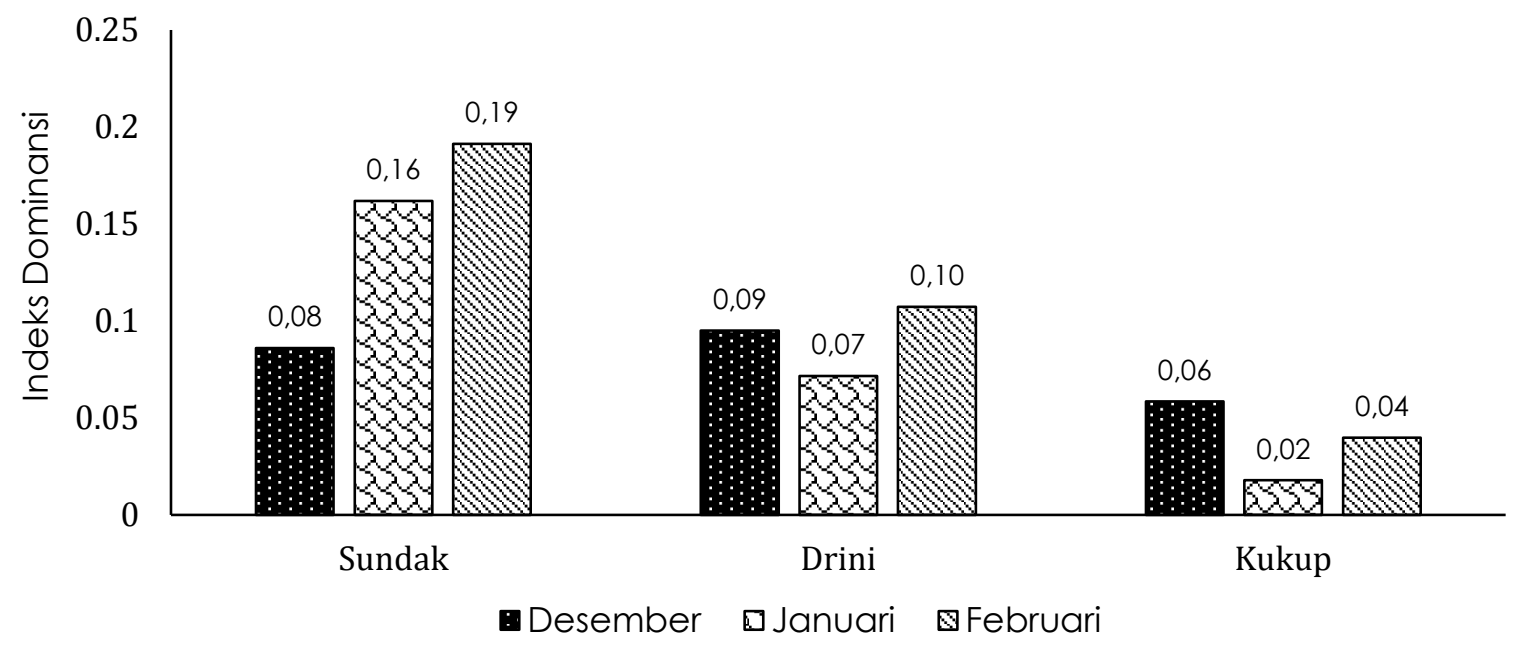

Gambar 6. Indeks dominansi plankton antar pantai

dtemukan Tintinopala sp. Sedangkan di zona intertidal Pantai Kukup spesies yang paling banyak dtemukan Skeletonema costatum dan Tintinnopsis butschlii. Menurut Rath et al (2018) Skeletonema spp. yang melimpah banyak ditemukan di perairan yang kaya nutrient, sehingga Pantai Kukup diduga mengandung banyak nutrient di perairan.

Parameter fisika dan kimia dalam suatu perairan sangat berperan penting dalam mempengaruhi kelimpahan, distribusi dan keanekaragaman plankton (Sharma et al., 2015). Menurut Chai et al. (2016), pengaruh fisika air seperti suhu, salinitas, kecerahan atau turbiditas, dan nutrient merupakan faktor penting yang mempengaruhi distribusi spasial dan temporal plankton. Suhu air diukur pada setiap pengambilan sampel dengan kisaran $29,5-32{ }^{\circ} \mathrm{C}$, sedangkan suhu udara lebih rendah berkisar $26,5-30{ }^{\circ} \mathrm{C}$. Suhu optimum untuk organisme laut tropis $25-29^{\circ} \mathrm{C}$ dengan suhu minimum $20^{\circ} \mathrm{C}$ dan suhu maksimum $36^{\circ} \mathrm{C}$ (Suharsono, 2008), sehingga suhu di ketiga pantai masih sesuai untuk kehidupan biota. Fluktuasi suhu yang rendah di Pantai Kukup mendukung keanekaragaman plankton yang lebih tinggi dibandingkan dengan Pantai Sundak dan Drini.

Derajat keasaman $(\mathrm{pH})$ berpengaruh terhadap kehidupan biota air, perairan yang terlalu asam atau basa dapat menyebabkan terjadinya gangguan metabolisme dan respirasi serta meningkatkan konsentrasi 

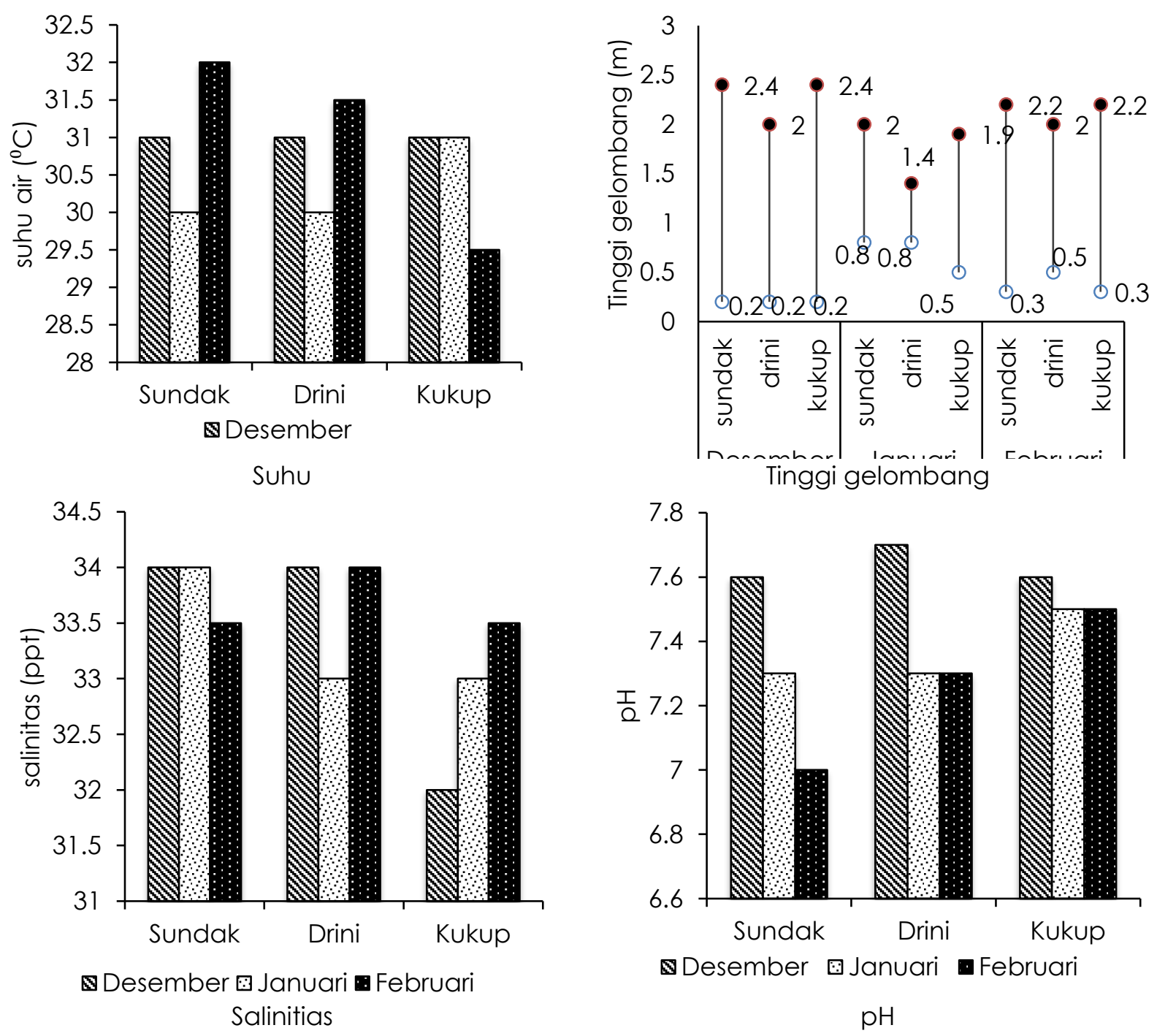

Gambar 7. Kondisi parameter lingkungan perairan Pantai Sundak, Drini, dan Kukup. Keterangan: data tinggi gelombang diambil dari aplikasi Global Tide

ammonia yang bersifat toksik bagi organisme (Barus, 2002). Nilai pH yang diperoleh selama pengambilan sampel berkisar 7,2-7,7 nilai tersebut tergolong baik untuk kehidupan biota. Menurut Rahayu et al., (2009) pH air 6,5-8,2 merupakan kondisi optimal untuk makhluk hidup. pH merupakan salah satu faktor yang mempengaruhi produktifitas perairan. Kumar \& Prabhahar (2012) menyatakan bahwa perairan dengan $\mathrm{pH}$ relative basa akan memicu peningkatan produktivitas primer dalam perairan tersebut. Fluktuasi $\mathrm{pH}$ yang rendah di Pantai Kukup dibandingkan dengan kedua pantai yang lain mendukung tingginya keanekaragaman plankton di Pantai Kukup.
Salinitas di Pantai Sundah relatif stabil dibandingkan Pantai Drini dan Kukup, sehingga hal ini mendukung kelimpahan plankton yang tertinggi. Salinitas di Pantai Kukup yang bervariasi diduga karena adanya aliran mata air tawar yang masuk menuju pantai. Data curah hujan selama pengambilan sampel didapatkan melalui BMKG Yogyakarta dengan nilai curah hujan pada bulan Desember $613 \mathrm{~mm}$, bulan Januari $444 \mathrm{~mm}$ dan Februari $344 \mathrm{~mm}$. Curah hujan tersebut tergolong dalam curah hujan tinggi karena nilainya $>300 \mathrm{~mm}$, sehingga masuk pada puncak musim penghujan. Curah hujan yang tinggi menyebabkan peningkatan nutrien dan sedimentasi yang 
masuk ke pantai. Hal ini mempengaruhi kelimpahan dan struktur komunitas plankton di zona intertidal.

\section{KESIMPULAN}

Kelimpahan plankton tertinggi terdapat di Pantai Kukup dengan rata-rata kemelimpahan 733 individu $\mathrm{L}^{-1}$. Indeks keanekaragaman tertinggi terjadi di Pantai Sundak dengan rata-rata sebesar 1,67 yang dikategorikan sedang dengan indeks dominansi rata-rata terendah sebesar 0,04 yang dikategorikan rendah. Kondisi habitat di zona intertidal Pantai Sundak, Drini, dan Kukup dalam keadaan baik dan seimbang.

\section{UCAPAN TERIMA KASIH}

Penelitian ini dibiayai oleh Fakultas Pertanian Universitas Gadjah Mada.

\section{DAFTAR PUSTAKA}

Acevedo-Trejos, E., Brandt, G., Bruggeman, J. \& Merico, A. 2015. Mechanism shaping structure and functional diversity of phytoplankton communities in the ocean. Scientific Reports. 5(8958): 1-8. doi: 10.1038/srep08918.

APHA. 1981. Standart Methode for The Examination of Water and Wastewater 15th Edition. American Public Health Assoiation. Washington DC.

APHA. 2005. Standard Methods for examination of water and wastewater. Twentieth edition. APHA-AWWA-WEF. Washington DC. 2-18pp.

Almen, K. \& Tamelander, T. 2020. Temperature-related timing of the spring bloom and match between phytoplankton and zooplankton. Marine Biology Research. 16(8-9):674-682. doi: 10.1080/17451000.2020.1846201

Alves-de-Souza, C., Pecqueur, D., Le Floc'h, E., Mas, S., Roques, C., Mostajir, B., Vidussi, F., Velo-Suárez, L., Sourisseau, M., Fouilland, E. \& Guillou, L. 2015. Significance of plankton community structure and nutrient availability for the control of dinoflagellate blooms by parasites: a modeling approach. PLOS ONE. 10(6):e0127623. doi: 10.137/journal. pone.0127623.
Barus, T. A. 2002. Pengantar Limnologi. Jurusan Biologi FMIPA. Universitas Sumatera Utara. Medan. 196p.

Bužančić, M., Gladan, Ž.N., Marasović, I., Kušpilić, G. \& Grbec, B. 2016. Eutrophication influence on phytoplankton community composition in three bays on the eastern Adriatic coast. Oceanologia. 58: 302-316. doi: 10.1016/j.oceano.2016. 05.003

Chai, C., Jiang, T., Cen, J., Ge, W \& Lu, S. 2016. Phytoplankton pigments and functional community structure in relation to environmental factors in the Pearl River Estuary. Oceanologia 58:201-211. doi: 10.1016/j.oceano.2016.03.001

Cheriton, O.M., McManus, M.A., Stacey, M.T. \& Steinbuck, J.V. 2009. Physical and biological controls on the maintenance and dissipation of a thin phytoplankton layer. Marine Ecology Progress Series. 378: 55-69. doi: 10.3354/meps07847

El-Sherbiny, M.M., Al-Aidaroos, A.M. \& GabAlla, A. 2011. Seasonal composition and population density of zooplankton in Lake Timsah, Suez Canal, Egypt. Oceanologia. 53(3):837-859. doi: 10.5697/ oc. 53-3.837

Fehling, J., Davidson, K., Bolsh, C.J.S., Brand, T.D. \& Narayanaswamy, B.E. 2012. The relationship between phytoplankton distribution and water column characteristics in North West European Shelf Sea Waters. PLoS One. 7(3):1-16. doi : 10.1371/journal.pone.0034098

Gharib, S.M., El-Sherif, Z.M., Abdel-Halim, A.M. \& Radwan, A.A. 2011. Phytoplankton and environmental variables as a water quality indicator for the beaches at Matrouth, south-eastern Mediterranean Sea, Egypts: an assessment. Oceanologia 53(3): 819-836.

Kumar, M.P. \& Prabhahar, C. 2012. Physicochemical parameters of river water: a review. Int. J. Pharm. Biol. Arch. 3: 13041312. doi : 10.1016/j.ejar.2015.11.004

McManus, M.A. \& Woodson, C.B. 2012. Plankton distribution and ocean dispersal. Review. The Journal of Experimental Biology. 215: 1008-1016. doi: 10.1242/jeb.059014

Mena, C., Reglero, P., Hidalgo, M., Sintes, E., Santiagi, R., Martin, M., Moya, G. \& Balbin, R. 2019. Phytoplankton community structure 
is driven by stratification in the oligotrphic Mediterranian Sea. Frontiers in Microbiology. 10:1-15. doi: 10.3389/fmi cb.2019.01698.

Nawrocka, L. \& Kobos, J. 2011. The trophic state of the Vistula Lagoon: an assessment based on selected biotic and abiotic parameters according to the Water Framework Directive. Oceanologia. 53(3):881-894. doi : 10.569 7/oc.53-3.881

Naylor, E. 2006. Orientation and navigation in coastal and estuarine zooplankton. Marine and Freshwater Behaviour and Physiology. 39(1):13-24. doi: 10.1080/1023 6240600593344

Nursuhayati, A.S., Yusoff, F.M. \& Shariff, M. 2013. Spatial and temporal distribution of phytoplankton in Perak Estuary, Malaysia, during monsoon season. Journal of Fisheries and Aquatic Sciences. 8(4):480493. doi: 10.3923 /jfas. 2013.480 .493

Odum, E.P. 2005. Fundamentals of Ecology. Brooks/Cole Publishing Company. 598p.

Paerl, H.W., Valdes, L.M., Pinckney, J.L., Piehler, M.F., Dyble, J. \& Moisander, P.H. 2003. Phytoplankton photopigments as indicator of estuarine and coastal eutrophication. BioScience. 53(10):953964. doi: 10.1641/0006-3568(2003)053[09 53:PPAIOE]2.0.CO;2

Qiu, X., Huang, T. \& Zeng, M. 2016. Differences in phytoplankton dynamics and community structure between a wet year and dry year in the Zhoucun Reservoir.
Journal of Freshwater Ecology. 31 (3):377391. doi: 10.1080/02705060.2016.1155183

Rahayu, S., R.H. Widodo, Van Noordwijk, M., Suryadi, I. \& Verbist, B. 2009. Monitoring Air di Daerah Aliran Sungai. World Agroforestry Center Southeast Asia Regional Office. Bogor-Indonesia. 104p.

Rath, A.R., Mitbavkar, S. \& Anil, A.C. 2018. Phytoplankton community structure in relation to environmental factors from the New Mangalore Port waters along the southwest coast of India. Environmental Monitoring Assessment. 190(8):1-24. doi: 10.1007/s10661-018-6840-y

Sharma, R.C., Singh, N. \& Chauhan, A. 2016. The influence of physic-chemical parameters on phytoplankton distribution in a head water stream of Garhwal Himalayas: A case study. Egyptian Journal of Aquatic Research. 42: 11-21. doi: 10.1016/j.ejar.2015.11.004

Shirota, A. 1996. The Plankton of South Vietnam: Freshwater and Marine Plankton Overseas Technology Cooperative Agency. Tokyo. $461 \mathrm{p}$.

Suharsono, Giyanto, Yahmantoro \& Munkajee, J.A. 2008. Changes of Distribution and Abundance of Reef Fish in Jakarta Bay and Seribu Island. Proceedings Coral Reef Evaluation Workshop Pulau Seribu, Jakarta, Indonesia. Subagjo Soemodihardjo (Ed). Unesco Jakarta Office dan LIPI, Jakarta. 